\title{
Effects of Work and Environmental Measurement Protocols in High Temperature Exposure
}

\author{
Mrs.Anjali Kadam,Mrs.Rohinee Barai,Mr.Ajit Harde \\ Asst. Prof., Mech.Engg.Dept,Priyadarshini J.L. College of Engg., Nagpur \\ Asst. Prof., Mech.Engg.Dept,PriyadarshiniJ.L.College ofEngg.,Nagpur \\ Asst. Prof., Mech.Engg.Dept,PriyadarshiniJ.L.College ofEngg.,Nagpur
}

\begin{abstract}
Nonoptimal environments often result in worker discomfort and loss of productivity in the workplace. The temperature in a workplace can strongly influence efficiency of task. Hot, humid conditions added to the demands of moderately heavy to heavy physical work may cause excessive stress and potential health risks by reducing a person's work capacity. Discomfort produced by exposure to conditions outside the comfort zone can distract a person from the task at hand and may increase the potential for unsafe act. Various factors affecting the feeling of comfort are temperature, humidity, air velocity, work load, clothing and radiant heat loss. By altering environmental protocols one can improve comfort within the discomfort zone. An attempt is made to investigate factors like temperature, humidity and determining continuous heat exposure for workers working in a hot environment. By altering environmental protocols one can prevent heat injuries like heat stroke, fatigue, irritation, discomfort, giddiness; disorientation at work. This paper discusses the effect of temperature and humidity for an industrial worker working in a hot environment.
\end{abstract}

Key words: environmental protocols, high temperature, humidity, industrial worker

\section{Introduction}

Heat stress is often a serious problem in industrially developing countries.There is several physiological mechanisms for regulating body temperature. These are under involuntary control by nerve cells in the hypothalamus and maintain the body temperature within a narrow range (about $37 \pm 0.5^{\circ} \mathrm{c}$ ). This process is known as "Thermoregulation". The body temperature exhibits daily variations. It peaks in the late afternoon and reaches its lowest level in the morning. In order to keep the body temperature within a narrow regulated zone, the amount of heat gained and lost by the body over short span of time must be equivalent. If the body gains an excessive amount of heat, there could be excessive sweating, dehydration, heat stroke and finally death may occur. There are two major ways of adapting to a hot environment through acclimation and acclimatization. The effect of exposure to heat and humidity in the health risk zone can range from dehydration to heat stroke, with potential for burns also. Reducing duration of exposures are used to bring extreme heat exposures back into discomfort zone. Body temperature is regulated very closely in order to provide the best environment for the chemical reactions essential to life. In the course of a day, if no heavy exercise is done, the variation in body core temperature is seldom more than $0.6^{\circ} \mathrm{c}$ for most people. Heat balance is maintained by increasing blood flow to the skin and by sweating in hot environment and by reducing circulation to the skin and by shivering in cold environments. Heat is generated by metabolism, muscular work and is removed from the body by convection, radiation and evaporation. As outside temperature is lowered below skin temperature, the rate of body heat loss by convection is increased. If outside temperature is raised above skin temperature, the body net loss of heat by radiation is reduced and evaporation and convection become the most effective ways to maintain body temperature. The heat balance equation for the body can be summarized as follows: $M \pm C \pm R-E= \pm S .{ }^{[1]}$

TABLE I. BODY HEAT BALANCE

\begin{tabular}{|l|l|}
\hline Term & Definition \\
\hline $\mathrm{M}$ & Metabolic heat gain \\
\hline $\mathrm{C}$ & Convective heat gain or loss \\
\hline $\mathrm{R}$ & Radiative heat gain or loss \\
\hline $\mathrm{E}$ & Evaporative heat loss \\
\hline $\mathrm{S}$ & Heat storage in or loss from the body \\
\hline
\end{tabular}

This paper emphasis on temperature and humidity and its effect on industrial worker facing continuous heat exposure like smelting, drying, boiler cleaning with maintenance, steam cleaning, ironing, extruding plastics, molding plastics, chemical manufacturing (heat-producing reactions).In addition, work in buildings that are not air-conditioned or work outside during the summer months in warm climates can result in significant 
heat and humidity exposure, especially if heavy physical effort is required. By altering environmental protocols one can prevent heat injuries due to continuous exposure to heat.

\section{Experimental Study}

A case study is conducted at milling shop of medium scale steel industry. In the shop three rolling stand are arranged in a line. Two workers at first rolling stand, four workers at second rolling stand and two workers at third rolling stand. From a furnace a bloom heated up to temperature of $1100^{\circ} \mathrm{c}-1200^{\circ} \mathrm{c}$ passes through three rolling stands. Continuous exposure to heat as eight hours shift is scheduled.

Instrument used for measurements is digital Hygro/thermometer(Model2086, Range:8-70 ${ }^{\circ} \mathrm{c}$, Relative humidity:5-95\%). Preferably 24 hours values should be recorded at workplace but in this case workers are working for four hours in eight hours of shift due to continuous heat exposure. Many problems of temperature discomfort are seasonal like summer. It is always wise to take measurements in worst conditions (summer days). Heat and humidity measurements in summer days for correct result were taken.

Two days data collection in summer for first shift at regular interval of half an hour by eight measurements starting from 9:30 am to 1:00 pm. Above measurement help to assess worst as well as peak of days temperature and humidity.

\section{Results and Discussion}

Study was carried at Ferroy Alloys Corporation Ltd. Nagpur. A medium scale steel industry. Among the various departments at FACOR rolling mill shop was one where workers used to face continuous heat exposure due to which worker used to face a lot of heat injuries and usually avoid working continuously. So these environmental protocols were affecting workers performance and reduce productive time. Table II shows time, temperature and relative humidity study between station one and station two study carried out during hot summer days standing 5 feet away from material and the maximum temperature is $45.5^{\circ} \mathrm{c}$. Table III shows time, temperature and relative humidity for station three carried during hot summer days standing 5 feet away from material and the maximum temperature is $44.1^{\circ} \mathrm{c}$. For other day Table IV Shows time, temperature and relative humidity for station one and two carried during hot summer days standing 5 feet away from material and the maximum temperature is $45.5^{\circ} \mathrm{c}$. For other day Table $\mathrm{V}$ shows time, temperature and relative humidity study at station three. Study carried out during hot summer days standing 5 feet away from material. Table VI and VII help in the assessment of the severity of the heat and humidity load work load for a 2-hour continuous exposure. By altering environmental protocols one can prevent heat injuries. As the station I\&II were very close to furnace it was observed that temperature data collected near to that was showing highest temperature .Maximum temperature during two days was $45.5^{\circ} \mathrm{c}$ and lowest relative humidity. A temperature and relative humidity extreme does affect efficiency of industrial worker.

TABLE II. TEMPERATURE, RELATIVE HUMIDITY STUDYAT HIGH TEMPERATURE BETWEEN STATION ONE,TWO

\begin{tabular}{|l|l|l|l|}
\hline Sr. No. & Time & Temperature $^{{ }^{\circ} \mathrm{c}}$ ) & Relative Humidity $(\%)$ \\
\hline 1 & $9: 30 \mathrm{am}$ & 42.1 & 28 \\
\hline 2 & $10: 00 \mathrm{am}$ & 42.4 & 28 \\
\hline 3 & $10: 30 \mathrm{am}$ & 43.1 & 25 \\
\hline 4 & $11: 00 \mathrm{am}$ & 43.5 & 25 \\
\hline 5 & $11: 30 \mathrm{am}$ & 44.7 & 20 \\
\hline 6 & $12: 00 \mathrm{pm}$ & 45.4 & 20 \\
\hline 7 & $12: 30 \mathrm{pm}$ & 45.5 & $<20$ \\
\hline 8 & $1: 00 \mathrm{pm}$ & 45.5 & $<20$ \\
\hline
\end{tabular}

TABLE III. TEMPERATURE,RELATIVE HUMIDITY STUDY AT HIGH TEMPERATURE AT STATION THREE

\begin{tabular}{|l|l|l|l|}
\hline Sr. No. & Time & Temperature $\left({ }^{\circ} \mathrm{c}\right)$ & Relative Humidity $(\%)$ \\
\hline 1 & $9: 30 \mathrm{am}$ & 37.5 & 28 \\
\hline 2 & $10: 00 \mathrm{am}$ & 38.4 & 25 \\
\hline 3 & $10: 30 \mathrm{am}$ & 38.9 & 30 \\
\hline 4 & $11: 00 \mathrm{am}$ & 38.8 & 25 \\
\hline 5 & $11: 30 \mathrm{am}$ & 40.1 & 20 \\
\hline 6 & $12: 00 \mathrm{pm}$ & 40.2 & 20 \\
\hline 7 & $12: 30 \mathrm{pm}$ & 42.1 & $<20$ \\
\hline 8 & $1: 00 \mathrm{pm}$ & 44.1 & $<20$ \\
\hline
\end{tabular}


TABLE IV. TEMPERATURE, RELATIVE HUMIDITY STUDY AT HIGH TEMPERATURE AT STATION ONE,TWO

\begin{tabular}{|l|l|l|l|}
\hline Sr. No. & Time & Temperature $^{\left.{ }^{\circ} \mathrm{c}\right)}$ & $\begin{array}{l}\text { Relative } \\
\text { Humidity (\%) }\end{array}$ \\
\hline 1 & $9: 30 \mathrm{am}$ & 42.2 & 28 \\
\hline 2 & $10: 00 \mathrm{am}$ & 42.5 & 28 \\
\hline 3 & $10: 30 \mathrm{am}$ & 44.1 & 20 \\
\hline 4 & $11: 00 \mathrm{am}$ & 44.7 & 20 \\
\hline 5 & $11: 30 \mathrm{am}$ & 45.2 & 20 \\
\hline 6 & $12: 00 \mathrm{pm}$ & 40.4 & 20 \\
\hline 7 & $12: 30 \mathrm{pm}$ & 42.1 & $<20$ \\
\hline 8 & $1: 00 \mathrm{pm}$ & 43.3 & $<20$ \\
\hline
\end{tabular}

TABLE V. TEMPERATURE, RELATIVE HUMIDITY STUDY AT HIGH TEMPERATURE AT STATION THREE

\begin{tabular}{|l|l|c|l|}
\hline Sr. No & Time & Temperature $\left({ }^{\circ} \mathrm{c}\right)$ & $\begin{array}{l}\text { Relative } \\
\text { Humidity }(\%)\end{array}$ \\
\hline 1 & $9: 30 \mathrm{am}$ & 37.5 & 28 \\
\hline 2 & $10: 00 \mathrm{am}$ & 38.4 & 28 \\
\hline 3 & $10: 30 \mathrm{am}$ & 38.6 & 20 \\
\hline 4 & $11: 00 \mathrm{am}$ & 38.8 & 20 \\
\hline 5 & $11: 30 \mathrm{am}$ & 40.1 & 20 \\
\hline 6 & $12: 00 \mathrm{pm}$ & 40.4 & 20 \\
\hline 7 & $12: 30 \mathrm{pm}$ & 42.1 & $<20$ \\
\hline 8 & $1: 00 \mathrm{pm}$ & 43.3 & $<20$ \\
\hline
\end{tabular}

TABLE VI PERMISSIBLE HEAT EXPOSURE THRESHOLD LIMIT VALUE ${ }^{[4]}$

\begin{tabular}{|l|l|l|l|}
\hline \multicolumn{3}{|c|}{ Work Load* ------- } & \\
\hline Work/rest regimen & Light & Moderate & Heavy \\
\hline Continuous work & $30.0^{\circ} \mathrm{C}\left(86^{\circ} \mathrm{F}\right)$ & $26.7^{\circ} \mathrm{C}\left(80^{\circ} \mathrm{F}\right)$ & $25.0^{\circ} \mathrm{C}\left(77^{\circ} \mathrm{F}\right)$ \\
\hline $\begin{array}{l}75 \% \text { Work, } \\
25 \% \text { rest, each hour }\end{array}$ & $30.6^{\circ} \mathrm{C}\left(87^{\circ} \mathrm{F}\right)$ & $28.0^{\circ} \mathrm{C}\left(82^{\circ} \mathrm{F}\right)$ & $25.9^{\circ} \mathrm{C}\left(78^{\circ} \mathrm{F}\right)$ \\
\hline $\begin{array}{l}50 \% \text { Work, } \\
50 \% \text { rest,each hour }\end{array}$ & $31.4^{\circ} \mathrm{C}\left(89^{\circ} \mathrm{F}\right)$ & $29.4^{\circ} \mathrm{C}\left(85^{\circ} \mathrm{F}\right)$ & $27.9^{\circ} \mathrm{C}\left(82^{\circ} \mathrm{F}\right)$ \\
\hline $\begin{array}{l}25 \% \text { Work, } \\
75 \% \text { rest, each hour }\end{array}$ & $32.2^{\circ} \mathrm{C}\left(90^{\circ} \mathrm{F}\right)$ & $31.1^{\circ} \mathrm{C}\left(88^{\circ} \mathrm{F}\right)$ & $30.0^{\circ} \mathrm{C}\left(86^{\circ} \mathrm{F}\right)$ \\
\hline
\end{tabular}

TABLE V MAXIMUM RECOMMENDED WORK LOADS, HEAT DISCOMFORT ZONE ${ }^{[1-251]}$

\begin{tabular}{|c|c|c|c|c|c|}
\hline \multicolumn{6}{|c|}{ Maximum recommended work load } \\
\hline \multicolumn{2}{|c|}{ Temperature } & \multicolumn{4}{|c|}{ Relative Humidity(\%) } \\
\hline${ }^{\circ} \mathrm{F}$ & ${ }^{\circ} \mathrm{C}$ & 30 & 40 & 60 & 80 \\
\hline 80 & 27 & Very Heavy & Very Heavy & Very Heavy & Heavy \\
\hline 90 & 32 & Very Heavy & Heavy & Moderate & Light \\
\hline 100 & 38 & Heavy & Moderate & Light & Not recommended \\
\hline 110 & 43 & Moderate & Light & Not recommended & Not recommended \\
\hline 120 & 49 & Light & Not recommended & Not recommended & Not recommended \\
\hline
\end{tabular}

\section{Conclusion}

As paper emphasis on temperature and humidity and its effect on industrial worker facing continuous heat exposure like smelting, drying, boiler cleaning with maintenance, steam cleaning, ironing, extruding plastics, molding plastics, chemical manufacturing (heat-producing reactions).Extended exposure to air with very low humidity can produce serious discomfort for some workers. Provision of humidified air through a respirator can be used to overcome drying effect. Flexibility in the scheduling of work and rest so that worker should self limit exposure to the heat. Training of workers in first aid principals to aid a person who experience heat/humidity illness. 


\section{References}

[1] The human factors section,health,safety and human factors laboratory "Ergonomic Design for people at work" Eastern Kodak Company, New York(1983)

[2] Heather Carnahan, Adam Dubrowski ,LawrenceE.M.Grierson, "Temperature influences both haptic perception and force production", International Journal of Industrial Engineering, 40(2010), 55-58

[3] E.K.O'Neal, P.Bishop "Effects of work in a hot environment on repeated performances of multiple types of simple mental task", International Journal of Industrial Engineering, 40(2010), 77-81

[4] www.osha.gov 